\title{
Žydų tautinès mažumos diskriminacijos patyrimas socialinių transformacijų kontekste
}

\author{
Gabija ČELEDINAITE் ${ }^{1}$ \\ Vilniaus universitetas
}

\begin{abstract}
Santrauka. Tautinių mažumų diskriminacijos patyrimas - jautrus ir Lietuvoje menkai tirtas klausimas, susijęs su ankstesniu traumų bei diskriminacijos išgyvenimu, santykiu su savo grupe ir aplinka, taip pat - Lietuvai specifinèmis socialinèmis transformacijomis, pakeitusiomis tautinių mažumų padètį, ir žydų tautybès atstovams specifiniais holokausto, kaip didžiausios įmanomos diskriminacijos, išgyvenimais. Tyrimo tikslas. Analizuoti, kaip Lietuvoje gyvenantys žydų tautybės asmenys patiria diskriminaciją. Metodika. Atliktas pusiau struktūruotas interviu, parengtas pagal tris pradinio tyrimo etapo biografinius interviu. Jame išskirtos dalys: tautinio tapatumo patyrimas, diskriminacijos išgyvenimas, socialinès transformacijos. Kalbètasi su 30 žydu tautybès asmenų (20-88 m.). Rezultatai ir išvados. Diskriminacija dažniau suvokiama kaip grèsmè sveikatai ar gyvybei - tai galima sieti su holokausto meto fizinès skriaudos patyrimu. Sovietiniais laikais rečiau užkliūdavęs kalbos aspektas, tačiau susidurta su užslẻpta diskriminacija, dažniausiai oficialiu lygmeniu. Diskriminacija nèra bendrinama visiems - diskriminuojantieji nuvertinami, ji siejama su nežinojimu, psichinèmis problemomis. Jos nepatiriantieji tai aiškina geru lietuvių kalbos mokèjimu ir gebejjimu išvengti situacijų, kuriose diskriminacija galètų pasireikšti.
\end{abstract}

Pagrindiniai žodžiai. Tautinė diskriminacija, tautinė mažuma, žydai, žydų tautybė, socialinės transformacijos

\section{İvadas}

Diskriminacija - tai kitoks elgesys su žmonėmis, grindžiamas pirmiausia jų priklausymu kitai socialinei grupei (Whitley \& Kite, 2010), galintis pasireikšti elgesiu ir verbaline išraiška ịvairiomis aplinkybėmis.

Diskriminacijos patyrimas skaudus, kad ir kokia forma ji reikštųsi. Diskriminacija laikoma tiesioginiu pavojumi asmens tapatybei (Schmitt \& Branscombe, 2002) - individas dažnai suvokia save pagal tai, kokiai socialinei grupei save priskiria lyties, rasės, amžiaus, religijos aspektu. Diskriminacijos patyrimas veikia žmogaus sveikatą. Diskriminacija siejama su nugaros skausmais (Edwards, 2008), išeminès širdies ligos rizika (Lewis et al., 2006), alkoholizmu (Lo \& Cheng, 2012), potrauminio streso sindromo simptomais (Cheng \& Mallinckrodt, 2015). Diskriminacija turi įtakos socialiniam gyvenimui - anksčiau diskriminaciją patyręs asmuo priešiškas tarpgrupines sąveikas dažniau linkęs suvokti kaip diskriminuojančias (Bombay et al., 2014). Taigi, ankstesnè neigiama patirtis lemia didesni jautrumą diskriminacijos užuomazgoms ir jos stiprumui. Taip susidaro uždaras diskriminacijos patyrimo ratas. Kad nepasikartotų nuoskaudos, tautinės mažumos atstovai buriasi ị uždaras grupes (Ajdukovic, 2004), stipriau identifikuojasi su sava grupe (Ramos et al., 2013), o toks išskirtinumo demonstravimas savo ruožtu skatina didesni aplinkos priešiškumą (Wirtz \& Doosje, 2013). Tai dar vienas sudedamasis veiksnys, darantis įtaką diskriminacijos patyrimui.

Išnagrinejjus atliktus tautinès diskriminacijos tyrimus aiškejja, kad socialiniai aspektai, kaip antai daugumos ir mažumos santykis šalyje, valstybine kalba ir istorinè patirtis, yra susiję su suvokiamu diskriminacijos lygiu (Zbarauskaite ir Čeledinaite, 2015). Vykstant specifinėms, didelę įtaką šalies gyventojų mentalitetui turèjusioms (Gailienė, 2008) socialinėms transformacijoms (Lietuvos nepriklausomybės praradimas ir atkūrimas), imta akcentuoti valstybinès kalbos mokèjimo ir buvimo lietuviu svarba - tai taip pat veikè tautinių mažumų padètị.

Žydų tautybès asmenys Lietuvoje susidūrè su visais išvardytais veiksniais, susijusiais su diskriminacijos suvokimu ir išgyvenimu. Greta to žydų tauta išsiskiria savo istorine patirtimi - tai holokaustas ir iš kartos i kartą perduodami su tuo susiję išgyvenimai. Diskriminacija yra siejama su istoriniais praeities įvykiais ar ilgą laiką gyvuojančiais papročiais (Nijakowski, 2009). Be to, žydų tautą lydintys stereotipai veikia jų santykị su aplinka - anot Bergmann (2008), antisemitizmas siejamas su grèsme tautos įvaizdžiui, o tai kuria atitinkamus prietarus ir tikejjimą stereotipais.

Taigi, žydų tautinė diskriminacija priklauso nuo daugybės atskirų veiksnių, kai kurie jų labai specifiniai. Šis tyrimas atliktas tam, kad geriau suprastume diskriminacijos patyrimą ir kaitą socialinių transformacijų kontekste. 


\section{Metodika}

Žydų tautinès mažumos diskriminacijos patyrimą Lietuvoje, vykstant socialinėms transformacijoms, siekta atskleisti kuo stipriau remiantis šios tautybės atstovų išsakytais subjektyviais išgyvenimais, todėl pasirinktas kokybinis tyrimas, atlikta teminè analizè.

\subsection{Tyrimo dalyviai}

Tyrimui pasirinkta žydų tautinė mažuma, nukentėjusi nuo stipriausios diskriminacijos formos - žudymo tautiniu pagrindu. Siekta išgirsti ịvairaus amžiaus ir ịvairia gyvenimo patirtị turinčius tautos atstovus.

Tyrimo dalyvių atranka vykdyta pasitelkus žydus vienijančias organizacijas - Lietuvos žydų bendruomenę ir Valstybinį Vilniaus Gaono žydų muziejų. Dalyviai buvo kviečiami susisiekus su jais iš vadovų gautais kontaktais arba tiesiogiai per organizacijose vykstančius renginius. Taip pat taikytas sniego gniūžtės principas - dalyvaujantieji tyrime padejjo įtraukti naujų dalyvių. Iš viso tyrime dalyvavo 30 žydų tautybès atstovų, 14 vyrų (47\%) ir 16 moterų (53 \%) nuo 20 iki $88 \mathrm{~m}$. amžiaus (vidurkis $-53,5 \mathrm{~m}$.).

\subsection{Tyrime naudoti instrumentai}

Autentiškiems tyrimo dalyvių išgyvenimams atskleisti naudotas pusiau struktūruotas interviu, kurtas remiantis pirminiais T. Wengraf (2004) biografinio pasakojimo metodu (angl. The Biographic Narrative Interpretive Method, $B N I M)$ atliktais interviu. Jų tikslas - išgirsti asmens gyvenimo istoriją, neprimetant nauju minčių ir idejjų, leidžiant atsiskleisti ir neịsisąmonintoms, kultūrinèms temoms.

Pagal pirminiuose interviu išryškejjusias temas buvo sudarytas trijų dalių pusiau struktūruotas interviu, naudotas pagrindiniame tyrimo etape. Jị sudarė klausimai apie subjektyvų tautinio tapatumo patyrimą, diskriminacijos išgyvenimą ir socialines transformacijas.

\subsection{Tyrimo eiga}

Tyrimo duomenys buvo renkami $2013 \mathrm{~m}$. sausị-2014 m. kovą dviem etapais: pradiniu, kurio metu rinkta informacija tyrimo instrumentui sudaryti, ir pagrindiniu, kai duomenys buvo renkami pusiau struktūruotu interviu.

Pradinio interviu metu trijų tyrimo dalyvių prašyta papasakoti savo gyvenimo istorija, visus ịvykius ir išgyvenimus, kurie buvo jiems asmeniškai svarbūs. Stengtasi nesikišti, tik skatinti tyrimo dalyvi kalbèti paties pasirinktomis temomis. Antroje tyrimo dalyje pusiau struktūruoto interviu metu kalbètasi su 27 dalyviais, užduoti klausimai apie subjektyvų tautinio tapatumo patyrimą, diskriminacijos išgyvenimą ir socialines transformacijas. Jais buvo prašoma prisiminti konkrečias situacijas iš savo ar artimujų patirties, atskleisti asmeninius išgyvenimus.

\subsection{Duomenu analizé}

Visi 30 interviu buvo įtraukti ị rezultatų analizę. Interviu buvo įrašomi diktofonu. Pokalbiai truko nuo 20 minučių iki 1,5 valandos. Interviu transkribuoti juos atlikusių tyrèjų. Surinkti duomenys analizuoti Boyatzis (1998) teminès duomenų analizės metodu. Siekiant užtikrinti rezultatų patikimumą, atrinkti keturi interviu buvo skaitomi keturiu ekspertų, kurie žymėjosi geriausiai tautinès mažumos atstovų diskriminacijos patyrimą atskleidžiančius epizodus. Tada išskirti elementai buvo palyginti, sujungti ị temas. Temų patikimumui šiame etape užtikrinti žydu grupès duomenys buvo lyginami su lenkų tautinès mažumos, dalyvavusios analogiškame tyrime, duomenimis, temos sujungtos ị kodus. Pagal juos buvo peržiūrèta ir užkoduota likusių interviu medžiaga.

Tyrejų nešališkumui ir duomenų patikimumui užtikrinti buvo atsižvelgta ị interviu metu pildytų kokybinio tyrimo dienoraščį pastabas. Transkribuotiems interviu koduoti ir kodams nagrinèti pasitelkta kokybiniams duomenims analizuoti skirta kompiuterine ATLAS.ti programa. Tyrimo išvados šiame straipsnyje iliustruojamos dalyvių citatomis.

\section{Rezultatai ir jų aptarimas}

Apie patiriamą diskriminaciją kalbama skirtingai - ji nurodoma kaip: I) patirta asmeniškai; II) juntama, tačiau asmeniškai sau nepriskiriama; III) patirta ne dèl specifinès tautybès, bet dèl to, kad asmuo nèra lietuvis. Vieniems diskriminuojantis elgesys - kone kasdienybė, jis lengvai atpažistamas ir suvokiamas kaip diskriminacija tautiniu pagrindu. Kiti išskyrimą dèl tautybès priima su lengvu humoru, neasmeniškai. Trečioji grupè nepabrèžia tautinio diskriminacijos aspekto, nors ir jaučiasi asmeniškai diskriminuojami.

Yra ir diskriminacijos nepatiriančiu žydų tautybės atstovu - taigi, ji paliečia ne visus, arba ne visuomet diskriminuojantis elgesys atpažistamas kaip toks. Vieni kalbẻjo, jog diskriminacijos nepatiria ir vèliau apie ją neužsiminè. Nepatiriantys diskriminacijos tautinès mažumos atstovai aktyviai ieško to priežasčiu - tai taip pat kalba 
apie diskriminacijos paplitimą - tarsi normalu būtų ją patirti, o nepatiriant tam reikalingas paaiškinimas. Tai dažnai siejama su individualiomis savybėmis: charakterio bruožais, profesiniais pasiekimais, savo tautybės nuslèpimu ar gebẻjimu išvengti situacijų, kuriose diskriminacija galètų pasireikšti. Kartu kyla mintis, kad net ir asmeniškai diskriminacijos nepatiriantiesiems gali būti nelengva gyventi valstybèje, kurioje jaučiamas priešiškumas savai tautinei mažumai ir kur reikia stengtis elgtis būtent taip, kad diskriminacijos būtų galima išvengti.

Kiti, nors teigè diskriminacijos nepatyrę, vèliau pasakojo apie ją: „,Ne. Dél to, kad esu žydè, tai va dèl to kažkaip nejaučiau. $<\ldots>0$, prisiminiau. Taip pasikapsčius atminty. Prisiminiau. Bet vèlgi, čia ne labiau mane grynai lietė, bet gal mano brolị. A, mane irgi, buvo vienas ten. Lietè “ (moteris, 26 m.). Dèl šio atsiskleidusio neatitikimo būtina išsamiau panagrineti, kaip žydų tautinės mažumos atstovai suvokia diskriminaciją

\subsection{Diskriminacijos suvokimo aspektai}

Retas kuris diskriminaciją jaučia kaip teigiamą išskyrimą. Dauguma ją suvokia kaip pavojų, neapykantą, ksenofobiją ar neigiamą išskyrimą apskritai - įžvelgia neigiamus jos aspektus.

Analizuojant duomenis pastebėta tendencija diskriminaciją dažniau ịvardyti kaip grèsmę sveikatai ar gyvybei (,,pas mus klasèj buvo berniukas, kur aiškiai buvo ir išvaizda, ir pavarde [žydiška], ir, žinok, būdavo, jị mušdavo. Vadindavo žydu ir mušdavo " (moteris, 36 m.). Tai galima sieti su holokausto kaip labai sunkios traumos patyrimu, užgožiančiu smulkesnes diskriminacijos apraiškas. Turint fizinės - stipresnès, labiau žeidžiančios - prievartos patirties, žodinè diskriminacija jaučiama kaip mažiau grèsminga, palyginti su tuo, kas glūdi atmintyje:

A: Ar buvo kokiu nors sunkumu, susijusiu su jūsu tautybe?

B: Nepasakyčiau. Tai buvo sunkumu tais holokausto metais, tada taip, žinoma, tada aš labai daug kentejau. Labai daug (vyras, $82 \mathrm{~m}$.).

Tačiau vyksta ir atvirkštinis procesas - kaip patvirtina Bombay (2014), kai kurie, turèdami fizinės diskriminacijos patirties, yra jautresni diskriminacijos ženklams dẻl baimès, kad bet koks priešiškumas gali nepastebimai išaugti i fizinę grèsmę (,,Su neonaciais nenoréčiau bendraut. <...> Tiesiog kampuoti, riboti žmonès, mane gal baugina fizine jèga"(vyras, 45 m.)).

Atsakymuose i klausimą apie diskriminacijos patyrimą greta šiandienès diskriminacijos situacijos iškyla holokausto tema, išryškèja i klausimo rẻmus sunkiai telpantis teiginys, kad holokaustas yra tarsi daugiau nei diskriminacija: „,Na, holokausta tai mano šeima praejo, be abejo. Tai čia... visos šeimos netekau iš tèvo pusès praktiškai. Tai.. be abejo [pauzè 4 s.]. Man tas žudymas - ne diskriminacija, tai yra konkretus antisemitizmas, tai yra buitinis, ir yra politinis “ (vyras, 45 m.). Kaip aptarta anksčiau, žmonių žudymas tautiniu pagrindu yra pripažįstamas aukščiausia įmanoma diskriminacijos forma, tačiau galima kelti prielaidą, jog žydų tautai istoriniai ịvykiai yra per skaudūs, kad juos būtų galima sulyginti su šiais laikais dažniau pasitaikančiomis diskriminacijos apraiškomis.

Tiesiogiai nepatyrus holokausto meto sunkumų, dabartinè patirtis gali būti lyginama su traumuojančiu tėvų, seneliu patyrimu (,, Seneliai gal daugiau. Kai jie turèjo bègti nuo naciu, slèptis. Tai jie gal daugiau pajaute tokiu dalyku. Tèvai gal jau nebe. Ir aš gal jau irgi nebe" (moteris, 26 m.)). Jaunesnioji karta, užaugusi nepriklausomoje Lietuvoje (20-36 metų asmenys), izžvelgia savo ir savo tėvų požiūrio i diskriminaciją skirtumą - anot jų, vyresnioji karta patiriamus sunkumus dažniau siejanti su tautine diskriminacija. Šie duomenys neprieštarauja Bombay (2014) ankstesnès išgyventos diskriminacijos ịtakos teorijai.

Taigi, diskriminacijos suvokimas, kurio pagrindas - neigiamų tautinio išskyrimo aspektų atpažinimas, priklauso ne tik nuo asmeninio patyrimo, bet ir nuo ankstesnių kartų patirties.

\subsection{Patiriama ir numanoma diskriminacija}

Atliktų interviu metu išryškejjo tendencija kaip diskriminaciją nurodyti konkrečius ịvykius, patirtų situacijų pavyzdžius, o ne bendrą sąvoką. Išskirtos dvi kategorijos - tai patiriami (realiai vykstantys) ir numanomi ịvykiai.

Kaip aiškiai diskriminuojančios nurodomos neonacių eitynès, jas paminèjo trečdalis apklaustujų. Čia taip pat išryškèja tarp žydų dažnas diskriminacijos kaip fizinès grèsmės suvokimas - apskritai neonacionalistai, arba „,skinhead 'ai “, grasina fizine jèga, kelia nerimą. Jaučiama ir nauja antisemitizmo banga (,,Vengrijoje tai labai kyla dabar tokia antisemitu partija, nacionalistu partija, kurie ten eis, jau nori sudarinèti [sarašus], kaip ir Suomijoje" (moteris, 20 m.)).

Tarp realiai vykstančių diskriminuojančių įvykių minimas pravardžiavimas bei įžeidinèjimas. Diskriminacija gali būti ịsišaknijusi kalbos struktūroje (Green, 2007), lietuvių kalba nėra išimtis - ir čia galima aptikti to užuomazgų. Patys žydai pastebi, kad bendrinis tautybès pavadinimas vartojamas įžeidžiančia, paniekinančia prasme (,,Kolegé <...> pasakè, kad ji pardavé savo mašina žydui ir iš karto manęs atsiprašèe: „Atleiskit, gal aš jus ǰžeidžiau“, kad ji paminèjo ,„žydu“. Aš net nesupratau, kad kažkur ĭ žyda žiūri paniekinančiai, o yra“ (moteris, $78 \mathrm{~m}$.)). 
Nagrinètuose interviu atsiskleidžia ir numanomos diskriminacijos tema. Dažniausiai tai - holokausto pasikartojimo galimybė, įžvelgiama antisemitiniame, nacionalistiniame judèjime. Apie ją kalbama su baime: „, Minios atmosfera veike ir Vokietijoj prie Hitlerio, ji gali veikti čia, vot kaip tik, neduok dieve, kažkas bus, prasidès pogromai, todèl, kad bus žmonès, kurie pradès šita ir pradès paskui kelt visa šita atmosfera" (vyras, 75 m.). Šioje citatoje atsispindi dalies žydų neapleidžianti mintis, kad aplinkinių tautinè neapykanta gali būti užkrečiama. Keliama hipotezè, jog tautos istorinès patirties pasèta baimè lemia didesnị įtarumą, skatina saugotis menkiausios grèsmès, nes ji galinti išaugti ị tautos tragediją.

Numanoma diskriminacija atsiskleidžia ir kalbant apie materialinę gerovę. Vyrauja nuostata, kad diskriminacijos lygis tiesiogiai proporcingas turimoms pareigoms: „Nepatyriau [diskriminacijos], <...> paskiau man neteko lipti karjeros laiptais. Jeigu aš daryčiau karjera kokioj nors valstybinej įmonèj arba privačioj didelej kompanijoj galbūt" (vyras, 50 m.). Tikima, kad aukštesnès pareigos gali paskatinti priešiškumą būtent tautiniu, o ne kokiu kitu pagrindu.

Dvejopa tyrimo dalyvių minima diskriminacija - patiriama ir numanoma - dar kartą primena, kokia daugialypė ši tema. Svarbu patyrinèti ir veiksnius, galinčius turèti įtakos diskriminacijai. Vienas jų - šalyje vykstančios socialinės transformacijos.

\subsection{Socialinès transformacijos Lietuvoje ir diskriminacija}

Sovietiniais laikais dėl žydų tautybės kildavo ịvairių sunkumų. Dažniausiai tai buvo diskriminacija, susijusi su darbu ar studijomis formaliu lygmeniu: (,... oficialiam lygyje, o iš savo draugu niekada nejutau. Antisemitizmas oficialus labai jautesi. Bet ne santykiuose tarp žmoniu “ (moteris, 78 m.)). Šiandien jaučiama grèsmè socialinei gerovei gali būti paaiškinama tuo, kad Tarybų Sajungos laikais nemažos dalies tyrimo dalyvių paminètoje ,penktojoje grafoje“" užfiksuota tautybė iš tiesų galejo lemti apribojimus, o jų baimė likusi iki šiol.

Sunku ịvertinti, kada diskriminacija reiškèsi stipriau: vieni teigia daugiau tautinès diskriminacijos patyrę Sovietų Sajungos laikais (,,Iš tos pozicijos, kad žydas - ne žydas, dabar tokiu nèra, nors buvo laikai ten Stalino metu, po Stalino ten buvo tokie dalykai “ (vyras, 75 m.)), kiti - nepriklausomoje Lietuvoje. Lyginant šiuos du laikotarpius paaiškejjo, kad diskriminacija tiesiog skyrèsi: sovietiniais laikais ji buvo labiau veidmainiška, įslaptinta. Nemaža dalis pripažino, jog tuomet slëpè savo tautybę (,, Taip, tarybiniais laikais tai nieks, nieks nežinojo. <...> mano dukra tai net nežinojo iki kokiu 15-os, 16-os metu, kokios aš kilmès esu “ (moteris, 58 m.)). Slèpti savo tautybę reiškia meluoti apie vieną pamatinių savasties aspektų (Schmitt \& Branscombe, 2002) - tai, nors padėdavo išvengti nemalonaus išskyrimo, galèjo sukelti skaudžių padarinių.

Šiais laikais diskriminacija dažniau yra anoniminè, tačiau atvira: pasikeitus technologijoms, viena stipriausių diskriminacijos formų tapo anoniminiai komentarai internete (,, visa ta neigiama nuomoné, ji ne iš žmoniu eina. Ji turbūt iš visokių ten iš delfi komentaru, < ..> pogrindiniai kažkokie upeliai informacijos, jie labai nuodija " (moteris, 49 m.)). Nors tai nèra tiesioginiai, asmeniniai įžeidimai, jie ịspèja apie bauginančią fizinę grèsmę (,paskaitykit atsiliepimus „,Delfi“ bet kokiam straipsny apie žydus $<\ldots>$ tiesiog nera drasos pasakyt i akis - tai yra tyliai su kirviu stovi, ir kai bus patogus momentas, reiškia, ta kirvị panaudos “ (vyras, $45 \mathrm{~m}$.)). Tyrime atsiskleidè tautinių mažumų atstovams kylantis klausimas, ar tai gali kilti iš užsakyto tautų priešinimo. Tokį nepasitikèjimą gali provokuoti anksčiau patirtos traumos, prieš žydų tautą vykdyto sąmokslo šešèlis.

Pastebètas skirtumas ir nagrinėjant tautini išskyrimą kalbos aspektu. Pripažinta, kad sunkumų dẻl realaus ar menamo lietuvių kalbos nemokejjimo patirdavo ir tuomet: „,Matot, ten reikia laiškus rašyti lietuviškai, gal jis nesugebés [juokiasi] - va tokie paaiškinimai “ (vyras, 75 m.), tačiau kai kurie tyrimo dalyviai teigia nejutę išskyrimo kalbos pagrindu. Atsiranda ir tokių, kuriems toks tautiečių išskyrimas tampa teigiamu dalyku - puikiai kalbantieji lietuviškai ši pranašumą išnaudoja kaip būdą apsiginti nuo tautinès diskriminacijos: „,[Sūnūs] sako, kad geriau nesakyti, kokios tu tautybès. Nes jie laisvai kalba lietuviškai, tai nieks negali įtarti “ (moteris, 38 m.). Ryškèja ir noras išvengti galimos diskriminacijos tobulai išmokstant lietuvių kalbą.

\subsection{Tautinès diskriminacijos išgyvenimas ir ịveika}

Diskriminacijos poveikis priklauso nuo to, kaip i ją reaguojama, kaip ji interpretuojama ir kokios įveikos naudojamos tvarkantis su nemaloniais potyriais.

Dažniausiai atsiskleidusi reakcija ị diskriminaciją - jos ignoravimas arba humoras. Kai kurie ị diskriminaciją reaguoja skaudžiai, pabrěždami neteisybę. Dažnas reagavimo būdas - fizinis ar žodinis atsakas į diskriminuojantị elgesi (,,Kaip reaguodavau? Du būdai yra reaguoti. Jeigu yra stipresnis, jị lieka nutylèt. Jeigu silpnesnis - tai smogdavai" (vyras, $65 \mathrm{~m}$.)). Atsiskleidè ir gana netikèta reakcija ị diskriminaciją. Tai švietimas, kovojimas su nežinojimu ir stereotipais, kartu skleidžiant lygybès idejjas ir norint sumažinti antisemitizmo apraiškų.

Kalbant apie dar tik nujaučiamą diskriminaciją, iškilo tikslingo tautybès slėpimo tema: tai pasireiškia savo tautybės nutylejjimu, tautinių atributų slèpimu ir vengimu situacijų, kuriose diskriminacija galètų pasireikšti (,,Esu apsiribojusi nuo, pavyzdžiui, komentarų skaitymo, kai kalbama apie žydus. Nu sukūriau savo pasaulị ir nelabai noriu tenai listi" (moteris, $38 \mathrm{~m}$.).

Kartais, atvirkščiai, kaip apsisaugojimas nuo galimo puolimo naudojamas principingas tautybės pasisakymas: 
„, tave, visa tavo šeima, tavo vaikus, ir veždavo, šaudydavo. Kai tu ta suvoki, tu galvoji, [...], nu neteisybe. Tau pasidaro pikta dèl to, juo labiau, tu supranti, kad galejai irgi ten būti, jeigu būtum biški anksčiau gimęs. Ta prasme, ir dèl to pykčio galbūt norisi taip išreikšti. Nu aš žydas - ir ka tu man? “(vyras, 23 m.).

Šioje citatoje atsispindi būdingas su baime sumišęs pyktis dèl praeityje patirtos diskriminacijos, tautos istorijos įtaka dabartiniam elgesiui, mintims ir jausmams.

Be jokios abejonès, diskriminacija kelia nemalonius išgyvenimus. Kad patyrimo stiprumas sumenkètų, diskriminuojantieji nuvertinami (,... tas Murza. Jis net negali manęs ǰžeisti, todèl, kad neskaitau jị sau lygiu“ (moteris, 78 m.)). Pabrèžiama lygybè - žmogus gali būti menkinamas už jo poelgius, tačiau ne pagal tautybę. Kaip diskriminacijos patyrimo ịveika pastebimas noras atsiskirti nuo daugumos, iš kurios buvo sulaukta diskriminacijos. Greta skamba ir supratimas, kad kalta ne visa tauta, o atskiri individai (,,ne visi vienodi buvo. Nusikaltèlis turi konkretu varda ir pavardę" (moteris, $78 \mathrm{~m}$.$) ) - siekiama nebendrinti tautinès diskriminacijos ir$ priešiškumo, o tai, remiantis Foster (2009), prognozuoja kur kas mažesnes pasekmes savijautai. Netgi atvirkščiai jaučiamas noras ir dedamos pastangos pritapti prie šios šalies žmonių.

Tautinè diskriminacija žydų tautybès asmenų siejama su: I) tamsumu, nežinojimu (,,ne diskriminacija, čia yra tokie, kaip pasakyti, neprotingu žmoniu pasisakymai“" (moteris, $58 \mathrm{~m}$.)); II) klaidingomis nuostatomis ir tikejjimu stereotipais; III) diskriminaciją palaikančiomis šeimos vertybėmis; ar net IV) psichinemis problemomis (,Ǎs, pavyzdžiui, žiūriu i tuos žmones kaip ị ne iki galo sveikus žmones ir man tai padeda " (vyras, 50 m.)). Taip tarsi ieškoma diskriminacijos neracionalumo ir sunkiai suvokiamos neapykantos paaiškinimų.

\section{Išvados}

Apibendrinus tyrimo duomenis, išaiškejjo, kad:

- Apie patiriamą tautinę diskriminaciją žydų tautinès mažumos atstovai kalba kaip apie I) asmeniškai patiriamą, II) asmeniškai sau nepriskiriamą ir III) patiriamą dėl buvimo kitataučiu apskritai.

- Diskriminacija dažniau suvokiama kaip grèsmè sveikatai ar gyvybei - tai galima sieti su holokausto meto fizinės diskriminacijos patyrimu.

- Sovietų Sajungoje diskriminacija dažniau jausta kaip veidmainiška, užslèpta, oficialiu lygmeniu, o šiandienėje Lietuvoje ji yra atvira, pasireiškianti kasdienèse situacijose, ypač neonacių judejjimu ir anoniminiais komentarais internete.

- Diskriminacijos įveikai padeda tai, kad ji nèra bendrinama visiems - diskriminuojantieji išskirtinai nuvertinami; ji siejama su nežinojimu, klaidingomis nuostatomis, net psichinėmis problemomis.

- Tautinès diskriminacijos nepatiriantieji tai sieja su gebejjimu išvengti situacijų, kuriose diskriminacija galètų pasireikšti, ir geru lietuvių kalbos mokejjimu. Temos aktualumas atsiskleidžia tuo, kad, net ir nepatiriant diskriminacijos, yra svarstomos jos priežastys.

\section{Padėka}

Atliktas tyrimas yra Vilniaus universitete vykdyto pagal visuotine dotaciją finansuoto projekto „Sunkiu traumu ir socialinių transformacijų psichologiniai padariniai ir jų įveika“" (dotacijos projekto Nr. VP1-3.1-ŠMM-07-K-02-023) dalis. Labai ačiū visai projekto tyrèjų komandai, o ypač - darbo vadovei dr. Astai Zbarauskaitei. 


\title{
Experience of Discrimination Among Jewish Ethnic Minority in the Context of Social Transformations
}

\author{
Gabija ČELEDINAITÉ \\ Vilnius university \\ gceledinaite@gmail.com
}

\begin{abstract}
Ethnic discrimination is a sensitive issue, still little explored in Lithuania. This study investigates how the Jewish minority in Lithuania experiences discrimination and how that changed since World War II. Methods. Semi-structured interviews were conducted with 30 Lithuanian Jews, 20 to 88 years old, 14 male (47\%) and 16 female $(53 \%)$. Thematic analysis was applied. Results. Ethnic discrimination is mostly named as life- or healththreatening. This could be related to the experience of physical discrimination during the holocaust. Discrimination in the Soviet times is described as more deceptive, mostly at official levels. One of the coping mechanisms is the non-generalizing approach: discriminators are depreciated, it is associated to ignorance, false attitudes, mental problems. Those who do not experience discrimination, relate it to the good knowledge of Lithuanian language and the ability to avoid likely threatening situations.
\end{abstract}

Keywords. Ethnic discrimination, Jews, Jewish minority, Lithuania

\section{Literatūra}

Ajdukovic, D. (2004). Social context of trauma and healing. Medicine, Conflict and Survival, 20, 2, 120-135. DOI: 10.1080/1362369042 000234717

Bergmann, W. (2008). Anti-semitic attitudes in Europe: A comparative perspective. Journal of Social Issues, 64 (2), 343-362. DOI: 10.1111/j.15404560.2008.00565.x

Bombay, A., Matheson, K., \& Anisman, H. (2014). Appraisal of discriminatory events among adult offspring of Indian residential school survivors: The influences of identity centrality and past perceptions of discrimination. Cultural Diversity and Ethnic Minority Psychology, 20 (1), 75-86.

Boyatzis, R. E. (1998). Transforming qualitative information: Thematic analysis and code development. United States of America, Sage publications, Inc.

Cheng, H.-L., \& Mallinckrodt, B. (2015). Racial/ethnic discrimination, posttraumatic stress symptoms, and alcohol problems in a longitudinal study of Hispanic/Latino college students. Journal of Counseling Psychology, 62 (1), 38-49.

Edwards, R. R. (2008). The association of perceived discrimination with low back pain. Journal of Behavioral Medicine, 31, 379-389. DOI: 10.1007/s10865-008-9160-9

Foster, M. D. (2009). Perceiving pervasive discrimination over time: Implications for coping. Psychology of Women Quarterly (33), 172-182. DOI: $10.1111 / \mathrm{j} .1471-6402.2009 .01487 . x$

Gailienė, D. (2008). Ka jie mums padaré. Lietuvos gyvenimas traumu psichologijos žvilgsniu. Vilnius: Tyto alba.

Green, J. (2007). Language: Blood libels. Critical Quarterly, 49 (1), 114-118.

Lewis, T. T., Everson-Rose, S. A., Powell, L. H., Matthews, K. A., Brown, C., Karavolos, K., \& Wesley, D. (2006). Chronic exposure to everyday discrimination and coronary artery calcification in African-American women: The SWAN heart study. Psychosomatic Medicine, 68, 362-368.

Lo, C. C., \& Cheng, T. C. (2012). Discrimination's Role in Minority Groups' Rates of Substance-Use Disorder. The American Journal on Addictions, 21, 150-156. DOI: 10.1111/j.1521-0391.2011.00205.x.

Nijakowski, L. M. (2009). Discrimination against minorities in Poland on the basis of history. The case of the memory collective "Grandfather in the Wehrmacht". International Journal of Sociology, 39, 3, 38-57. DOI 10.2753/IJS0020-7659390302.

Ramos, M. R., Jetten, J., Zhang, A., Badea, C., Iyer, A., Cui, L., \& Zhang, Y. (2013). Minority goals for interaction with the majority: Seeking distance from the majority and the effect of rejection on identification. European Journal of Social Psychology (43), 72-83. DOI: 10.1002/ejsp.1915.

Schmitt, M. T., \& Branscombe, N. R. (2002). The meaning and consequences of perceiving discrimination in disadvantaged and privileged social groups. In W. Stroebe, M. Hewstone (Eds.), European Review of Social Psychology (Vol. 12, pp. 167-199). Chichester, UK: Wiley. Wengraf, T. (2004). The Biographic-Narrative Interpretive Method (BNIM) shortguide. Princes Avenue, London.

Whitley, B. E., \& Kite, M. E. (2010). The psychology of prejudice and discrimination (2nd ed.). Wadsworth: Cengage Learning.

Wirtz, C., \& Doosje, B. J. (2013). Reactions to threatening critical messages from minority group members with shared or distinct group identities. European Journal of Social Psychology, 43, 50-61. DOI: 10.1002/ejsp.1910.

Zbarauskaitė, A. ir Čeledinaitè, G. (2015). Tautinių mažumų diskriminacijos suvokimas ir išgyvenimas socialinių transformacijų kontekste. Iš D. Gailienè (sud.) Gyvenimas po lūžio. Kultūriniu traumu psichologiniai padariniai. Vilnius: Eugrimas. 